\title{
The Strategy of Preventing COVID-19 Infection for Dental Clinics in Taiwan
}

\author{
Ya-Ai Cheng ${ }^{1}$, Kuang-Min Hsieh ${ }^{2}$, Sin-Yen Hsieh ${ }^{1}$, and \\ Yueh-Tzu Kao'*
}

'Department of Healthcare Administration, I-Shou University, No. 8,Yida Rd., Yanchao Dist., Kaohsiung City 824, Taiwan (R.O.C)

${ }^{2}$ Department of Dentistry, Taipei Medical University, No. 250,Wuxing St., Xinyi Dist., Taipei City 110,

Taiwan (R.O.C)

Received: 20 April, 2020

Published: 25 April, 2020

*Corresponding author: Yueh-Tzu Kao, Department of Healthcare Administration, I-Shou University, No. 8,Yida Rd., Yanchao Dist., Kaohsiung City 824, Taiwan (R.O. C.) E-mail: ykao@isu.edu.tw

Keywords: COVID-19; Infection control; Dental clinic https://www.peertechz.com

Check for updates

\begin{abstract}
Coronavirus disease 2019 (COVID-19) is spread in the world. To understand how to prevent virus infection in dental clinics, case study is used in this study. Following SARS prevention, measuring body temperature, using mask, using dispersal instruments and spraying $75 \%$ alcohol are included. And clinics build standard operation procedure from patient arriving to treatment finished. Recording travel history, arranging the number of patients and accompany person are included. Isolate droplets and avoid the short distance of social contact are applied in the strategy.
\end{abstract}

\section{Introduction}

Coronavirus disease 2019 (COVID-19) is an infectious disease caused by severe acute respiratory syndrome coronavirus 2 (SARS-CoV-2) [1]. Common symptoms include fever, cough, and shortness of breath [2]. As of 19 April 2020, more than 2.34 million cases have been reported across 185 countries and territories [3], resulting in more than 161,000 deaths. The current tendency of COVID-19 epidemic is increasing and spreading in the world.

The virus is primarily spread between people during close contact, often via small droplets produced by coughing, sneezing, or talking. While these droplets are produced when breathing out, they usually fall to the ground or onto surfaces rather than being infectious over long distances. People may also become infected by touching a contaminated surface and then touching their eyes, nose or mouth [4].

In Taiwan, the first case was found on 29 Dec 2019. On 19 April 2020, Cumulative total of 420 cases have been reported, resulting 6 deaths [5]. Because of SARS invasion on $22 \mathrm{Feb}$, 2003 [6], Taiwanese people care a lot about this COVID-19 epidemic. This study is a case study to understand the strategy for preventing COVID 19 infection in dental clinics in Taiwan.

\section{Results}

The study object is a chain clinic. There are 8 dental clinics in Taiwan. Both interviewing staff and observation are used to collect information. After SARS invasion, the dental clinic separates each unit, uses disposable checking instruments, chair cover, and handle cover to prevent infection. Except above mentioned, the dental clinic builds its standard operation procedure (SOP) on this epidemic (Table 1). Staffs and patients need measure body temperature while entrance the clinic. Persons who get fever cannot go in clinic. Travel history need recorded. Because of droplets created during dental treatments, patient and accompany person need use surgical mask when they are in the clinic. In the treatment, staffs need use mask, gloves, translated face cover, and isolation gown. After each treatment, $75 \%$ alcohol is used to spray the chair. For social distancing strategies, patients recommend sit separately in waiting area. Control the numbers of dental appointment is also recommended.

\section{Conclution}

Currently, there is no vaccine or specific antiviral treatment for COVID-19. Personal hygiene can avoid virus infection and 
Table 1: Standard operation procedure for reducing the chances of COVID 19 infection in dental clinics

\begin{tabular}{|c|c|c|}
\hline Place & Staff & atient \\
\hline Entrance & $\begin{array}{l}\text { 1. Post preventive information } \\
\text { 2. Measure body temperature: is } \\
\text { out of dental clinic and recom } \\
\text { as possible. } \\
\text { 3. Use surgical mask }\end{array}$ & $\begin{array}{l}\text { te person who get fever } \\
\text { nd go to hospital as soon }\end{array}$ \\
\hline Waiting area & $\begin{array}{l}\text { Control the numbers of patients and } \\
\text { accompany persons }\end{array}$ & $\begin{array}{l}\text { 1. Arrange single seat } \\
\text { or seats separately } \\
\text { Single seat or } \\
\text { seats separately } \\
\text { 2. Keep the safe } \\
\text { distance of social } \\
\text { contact } \\
\text { 3. Use mask }\end{array}$ \\
\hline Treatment & $\begin{array}{ll}\text { 1. } & \text { separate each unit } \\
\text { 2. Use mask } \\
\text { 3. Use gloves } \\
\text { 4. Use translated face cover } \\
\text { 5. Use isolation gown. } \\
\text { 6. use disposable checking } \\
\text { instruments }\end{array}$ & Use mask \\
\hline $\begin{array}{c}\text { After } \\
\text { treatment }\end{array}$ & $\begin{array}{ll}\text { 1. } & \text { Spray } 75 \% \text { alcohol } \\
\text { 2. } & \text { Change chair cover } \\
\text { 3. } & \text { Change handle cover } \\
\text { 4. } & \text { Separate appointments }\end{array}$ & \\
\hline
\end{tabular}

offer references for preventive strategy. Both staffs and patients need to participate the strategy of preventing virus infection.

\section{References}

1. Coronavirus disease 2029 (2020) (Covid-19)-Symptoms and causes. Mayo Clinic Link: https://mayocl.in/3bCNznA

2. Symptoms of Coronavirus (2020) U.S. Centers for Disease Control and Prevention (CDC). Link: https://bit.ly/3bC6bnx

3. Coronavirus Update (live) (2020): 1,001,069 Cases and 51,378 Deaths from COVID-19 Virus Outbreak-Worldometer. Link: http://www.worldometers.info.

4. Q\&A on Coronaviruses (2020) World Health Organization.

5. Coronavirus disease 2019 (2020) (COVID 19). Taiwan centers for Disease Control.

6. Liao HC (2008) The Delimma of Being Hospital Workers: the SARS Crisis of Taiwan. Formosan J Med Humanities 9: 51-58. Link: https://bit.ly/2Y2rHOg
Discover a bigger Impact and Visibility of your article publication with

Peertechz Publications

\section{Highlights}

* Signatory publisher of ORCID

* Signatory Publisher of DORA (San Francisco Declaration on Research Assessment)

* Articles archived in worlds' renowned service providers such as Portico, CNKI, AGRIS, TDNet, Base (Bielefeld University Library), CrossRef, Scilit, J-Gate etc

* Journals indexed in ICMJE, SHERPA/ROMEO, Google Scholar etc.

* OAI-PMH (Open Archives Initiative Protocol for Metadata Harvesting)

* Dedicated Editorial Board for every journal

* Accurate and rapid peer-review process

* Increased citations of published articles through promotions

* Reduced timeline for article publication

Submit your articles and experience a new surge in publication services (https://www.peertechz.com/submission).

Peertechz journals wishes everlasting success in your every endeavours.

Copyright: (c) 2020 Cheng YA, et al. This is an open-access article distributed under the terms of the Creative Commons Attribution License, which permits unrestricted use, distribution, and reproduction in any medium, provided the original author and source are credited. 